\title{
Perspectives on skin disorder diagnosis among people living with HIV in southeastern Romania
}

\author{
MIRUNA DRAGANESCU ${ }^{1 *}$, LILIANA BAROIU ${ }^{1}$, ALINA IANCU $^{2}$, \\ CATERINA DUMITRU ${ }^{3 *}$, DIANA RADASCHIN ${ }^{1}$, EDUARD DRIMA POLEA ${ }^{1 *}$, CARMEN BOBEICA $^{4}$, \\ ALIN LAURENTIU TATU $^{1}$, ELENA NICULET ${ }^{2}$ and GYULA LASZLO FEKETE ${ }^{5}$
}

\begin{abstract}
Departments of ${ }^{1}$ Clinical Medicine, ${ }^{2}$ Morphological and Functional Sciences, and ${ }^{3}$ Pharmaceutical Sciences, Faculty of Medicine and Pharmacy, 'Dunărea de Jos' University, Galaţi 800010; ${ }^{4}$ Department of Demato-Venereology, Doctoral School, 'Grigore T. Popa' University of Medicine and Pharmacy, Iași 700115; ${ }^{5}$ Department of Dermatology,

‘George Emil Palade' University of Medicine, Pharmacy, Science and Technology, Târgu Mureș 540142, Romania
\end{abstract}

Received September 21, 2020; Accepted October 21, 2020

DOI: $10.3892 / e t m .2020 .9529$

\begin{abstract}
The beginnings of the human immunodeficiency virus (HIV) pandemic are closely linked to dermatological conditions. A large part of the population living with HIV (PLWH) has a series of skin conditions that determine at some point, a visit to the dermatologist. The introduction of highly active antiretroviral therapy (HAART) more than 20 years ago has diminished the range of dermatological conditions, with improved immunosuppression of CD4 lymphocytes. The study aimed to describe the prevalence of the diagnosed type of skin changes in PLWH receiving antiretroviral therapy and their stratification according to the degree of immunodeficiency. A prospective study was conducted on 57 PLWH evaluated monthly at an HIV outpatient clinic, from a tertiary hospital in southeastern Romania. Clinical examination and dermoscopy revealed the existence of a wide range of dermatological conditions; all 57 patients (100\%) being diagnosed with one or more dermatological conditions. As our study shows, the prevalence of different dermatoses among PLWH varies depending on the geographical region. At the same time, under HAART, the image of dermatoses associated with decreased immunity from HIV infection has changed. The skin changes of PLWH no longer fully follow the classical staging, based on the degree of immunosuppression.
\end{abstract}

Correspondence to: Dr Liliana Baroiu, Department of Clinical Medicine, Faculty of Medicine and Pharmacy, 'Dunărea de Jos' University, Strada Al. I. Cuza 35, Galați 800010, Romania

E-mail: lilibaroiu@yahoo.com

Mrs. Alina Iancu, Department of Morphological and Functional Sciences, Faculty of Medicine and Pharmacy, 'Dunărea de Jos' University, Strada A1. I. Cuza 35, Galați 800010, Romania

E-mail: iancualina.2003@yahoo.com

*Contributed equally

Key words: diagnosis, dermoscopy, HIV status, skin disorders, immunodeficiency

\section{Introduction}

The skin follows the intestine and other mucous tissues, as one of the barriers against pathogens. The skin contains innate or acquired immune response effectors. At this level immune conflicts in the skin are also manifested as a result of an abnormal or exaggerated immune response. Along with non-specific immunity effectors, most of the specific immunity effectors in the dermis include various subsets of T lymphocytes, including regulatory $\mathrm{T}$ lymphocytes, a population of CD4 receptor-expressing lymphocytes. The major role of CD4 lymphocytes at the skin level is to determine the resolution of inflammatory processes produced by various pathogens as well as the prevention of autoimmune phenomena (1). CD4 ${ }^{+}$ lymphocytes are also heavily involved in human immunodeficiency virus (HIV) infection, being the primary and the favorite targets of the HIV virus. The action of HIV on this type of lymphocyte is clinically translated by the decrease in the absolute and the percentage number, which determines the decrease of the specific action at the skin level and the perpetuation of the inflammatory phenomena with clinical expression (2).

A large part of the population living with HIV (PLWH) has a series of skin conditions that at some point require treatment by a dermatologist. It is estimated that PLWH require over 15 times more visits to the dermatologist than non-infected patients (3). The beginnings of the HIV pandemic are closely linked to dermatological conditions including Kaposi's sarcoma, a rare onco-dermatological condition which has been reported to be common among young gay males. Along with the occurrence of acquired immunodeficiency syndrome (AIDS) other dermatological conditions such as extensive oral candidiasis, herpes zoster and oral hairy leukoplakia have been described as indicators for this syndrome (4). The introduction of highly active antiretroviral therapy (HAART) more than 20 years ago has diminished and altered the range of dermatological conditions, with improved immunosuppression of CD4 lymphocytes $(5,6)$. However, PLWH still face a number of viral skin infections, chronic inflammation or various forms of skin cancer (5). Understanding the complex relationship between 
the immune system and dermatoses suffered by PLWH can lead to a better therapeutic approach and appropriate management.

There are no data available in Romania on the skin health of patients with HIV infection or the general population, neither globally nor regionally (southeastern region), except for various cases of malignancies (Kaposi' sarcoma, Paget's disease) reported for patients with HIV or manifestations of human papilloma virus (HPV) infection in the general population (7-11). Based on these grounds, we conducted this study to investigate the skin health of PLWH in the southeastern part of Romania.

The objective of this study was to describe the current skin disorders in PLWH receiving antiretroviral therapy (ARVT) to evaluate the prevalence of dermatoses diagnosed (type of skin changes), to stratify these changes according to the degree of immunodeficiency and to compare these skin disorders with those reported in the general population.

\section{Patients and methods}

Patients. We conducted a prospective study on 57 PLWH, undergoing monitoring and treatment at the HIV Outpatient Clinic, of the Infectious Diseases Hospital Sf. Cuv. Parascheva', Galati, Romania, evaluated monthly, between 1/10/2019 and $31 / 03 / 2020$. The study was conducted with the approval of the Ethics Commission of the Infectious Diseases Hospital Sf. Cuv. Parascheva', Galati, Romania (no. 65 from 30/09/2019). All patients signed informed consent to participate in this study.

Examination. Patients who gave their consent were clinically examined and by dermoscopy within a screening programme by an experienced dermatologist. Dermoscopy was performed with a Heine (Heine Optotekhnic) device. Bacterial, viral and fungal infections were diagnosed clinically without the involvement of laboratory investigations. Data on the mode of infection, place of residence, duration of disease and ARVT, level of CD4 lymphocytes and viral load (VL), treatment regimen and dermatological history were taken from the patient files. The most recent values of CD4 and VL lymphocytes were considered during the last 6 months. The CD 4 count was performed by the flowcytometry method with the Cyflow (Partec) device and the VL load was determined by RT-PCR (real-time polymerase chain reaction) at the National Institute of Infectious Diseases 'Prof. dr. Matei Bals' of Bucharest, Romania.

Statistical analysis. Statistical analysis was performed with MedCalc 19.5.3 software (https://www. medcalc.org) (12). Statistical analysis of the demographic data was performed on the group of patients with skin disorders and HIV infection with antiretroviral therapy. The data are expressed as mean \pm SD (standard deviation) for continuous variables and in absolute frequency (relative frequency) for categorical variables.

\section{Results}

The study group was composed mostly of female patients $(57.9 \%)$, from rural areas $(59.6 \%)$ with an average age of
Table I. Demographic characteristics of the PLWH study group.

\begin{tabular}{|c|c|}
\hline Features & Data \\
\hline \multicolumn{2}{|l|}{$\operatorname{Sex}, \mathrm{n}(\%)$} \\
\hline Male & $24(42.1)$ \\
\hline Female & $33(57.9)$ \\
\hline Age in years, mean (range) & $34.6(16-70)$ \\
\hline \multicolumn{2}{|l|}{ Environment of residence, $\mathrm{n}(\%)$} \\
\hline Urban & $23(40.4)$ \\
\hline Rural & $34(59.6)$ \\
\hline \multicolumn{2}{|l|}{ Means of infection, n (\%) } \\
\hline Early in infancy & $32(56.1)$ \\
\hline Sexually & $21(36.9)$ \\
\hline Vertically & $4(7.0)$ \\
\hline \multicolumn{2}{|l|}{ CD4 lymphocyte value (cells $/ \mathrm{mm}^{3}$ ) } \\
\hline Total, mean \pm SD (range) & $528 \pm 292.8(5-1,092)$ \\
\hline $\mathrm{CD} 4>500, \mathrm{n}(\%)$ & $32(56.0)$ \\
\hline CD4=499-200, n (\%) & $14(24.5)$ \\
\hline CD4 <200, n (\%) & $11(19.5)$ \\
\hline $\mathrm{VL}$, mean $\pm \mathrm{SD}$ (range), copies/ml & $371 \pm 1,879(10-12,864)$ \\
\hline$<20, \mathrm{n}(\%)$ & $47(82.5)$ \\
\hline$>20, \mathrm{n}(\%)$ & $10(17.5)$ \\
\hline \multicolumn{2}{|l|}{ Classification CDC, n (\%) } \\
\hline Stage A & $8(14.0)$ \\
\hline Stage B & $23(40.4)$ \\
\hline Stage C & $26(45.6)$ \\
\hline
\end{tabular}

Disease duration in years,

mean $\pm \mathrm{SD}$ (range)

$14.9 \pm 7.2(1-26)$

Disease duration according

to the mode of infection

Mean \pm SD (range), years

Early in infancy

$17.8 \pm 6.8(1-26)$

Sexually

$7.6 \pm 5.5(1-20)$

Vertically

$14.2 \pm 3.5(10-16)$

ARVT (\% of patients)

$100 \%$

ARVT (duration in years),

mean (range)

$13.5(1-25)$

CD4, T-lymphocyte cell-bearing CD4 receptor; VL, viral load; PLWH, population living with HIV; CDC, United States Centers for Disease Control and Prevention (31); ARVT, antiretroviral treatment.

34.6 years (range 16-70 years). The average value of CD4 lymphocytes was 528 cells $/ \mathrm{mm}^{3}$ and the average VL was 371 copies $/ \mathrm{mm}^{3}$. Most patients were in clinical-immunological stage $\mathrm{C}$, the mean duration of the disease was 14.9 years and the mean duration of treatment was 13.5 years (Table I).

In regards to the manner of acquiring the infection, most of the PLWH (56\%) came from the former 'pediatric cohort' of Romanian patients born between 1987 and 1990; all from seronegative parents, infected in the first months of life by parenteral care maneuvers. They have a long condition 
Table II. Range of dermatological lesions identified in PLWH in the study in correlation with immune status.

\begin{tabular}{|c|c|c|c|c|}
\hline Dermatological disease & $\begin{array}{c}\text { Prevalence } \\
\text { in PLWH (\%) }\end{array}$ & $\begin{array}{c}\text { General population } \\
\text { prevalence }(\%)\end{array}$ & $\begin{array}{c}\mathrm{CD}_{4}\left(\text { cells } / \mathrm{mm}^{3}\right) \\
\text { Mean } \pm \mathrm{SD}(\text { range })\end{array}$ & $\begin{array}{c}\text { Age (years) } \\
\text { Mean } \pm \text { SD (range) }\end{array}$ \\
\hline Bacterial & 3.5 & $1.4-7.7$ & $83 \pm 14.1(75-90)$ & $30.2 \pm 2.12(29-32)$ \\
\hline Foliculitis & 1.75 & & & \\
\hline Impetigo & 1.75 & & & \\
\hline Viral & 5.25 & 3.2 & $404 \pm 313(54-656)$ & $27.3 \pm 5.5(21-31)$ \\
\hline Herpes simplex & 3.5 & & & \\
\hline Vulgar warts & 1.75 & & & \\
\hline Fungal pitiriazis versicolor & 8.8 & $1.1-50$ & $816 \pm 116.6(691-923)$ & $32.3 \pm 2.5(30-35)$ \\
\hline Inflammatory psoriasis & 1.75 & 2 & 47 & 57 \\
\hline Malignant/premalignant nevocellular nevi & 30 & $4.4-60$ & $486 \pm 279(27-980)$ & $29.8 \pm 6.9(16-46)$ \\
\hline Other & 43.7 & & $523 \pm 316.3(59-1036)$ & $33.2 \pm 8.06(20-58)$ \\
\hline Microangiomas & 14 & $2.35-11.3$ & & \\
\hline Seborrheic dermatitis & 10.5 & $9-10.3$ & & \\
\hline Acne & 7 & 7.7 & & \\
\hline Cutaneous xerosis & 5.2 & 2.6 & & \\
\hline Papular pruritic exanthemas & 3.5 & 12.3 & & \\
\hline Follicular keratosis & 1.5 & 40.0 & & \\
\hline Stretch marks & 1.5 & 43.0 (for obesity) & & \\
\hline Papilloma & 3.5 & 36.0 & & \\
\hline Dermatofibroma & 1.5 & 3.0 & & \\
\hline
\end{tabular}

PLWH, population living with $\mathrm{HIV}$; $\mathrm{CD}_{4}$, T-lymphocyte cell bearing CD4 receptor.

duration, i.e. 17.8 years on average. This population has experienced the full range of specific therapies, being long-term survivors $(13,14)$. More than $1 / 3$ of the patients $(36.9 \%)$ were sexually infected while vertical transmission from mother to newborn was the least common form of infection, as a result of the introduction in 1992 in Romania of mandatory testing to all pregnant women before giving birth. The results of clinical examination and dermoscopy are shown in correlation with immune status (Table II); all patients being diagnosed with one or more dermatological conditions. The most common diseases $(43.7 \%)$ were skin changes that cannot be attributed to an obvious etiology and fall into the heterogeneous group of other dermatoses: Skin xerosis, seborrheic dermatitis, acne and keratoses followed by malignant/premalignant nevocellular nevi $(30 \%)$. The percentages of the different dermatological diseases of the HIV patients in our study were compared with the data from literature about the prevalence of these diseases, in the general population (Table II). These percentages are comparable, which suggests that the compensated immune status of the HIV-infected patients with antiretroviral therapy has minimal impact on skin damage.

The dermatological pathology described classically in the literature, in PLWH $(15,16)$, the bacterial and viral forms, was limited to sporadic cases of impetigo, herpes simplex or vulgar warts, and cases of pityriasis versicolor for the fungal etiology. In Table III, the dermatological conditions associated with various degrees of severity of HIV infection, were compared between two clinical studies from 2007 and 2019 and those pathologies diagnosed in patients in our group.

\section{Discussion}

The present study revealed that even with restored immunity under antiretroviral therapy and normal or quasi-abnormal values of $\mathrm{CD}^{+}$lymphocytes, the population living with HIV (PLWH) from southeast of Romania, showed a wide range of dermatological conditions with different prevalence. All $57(100 \%)$ patients of the study had various skin changes and $54(95 \%)$ of them had at least two combinations of dermatoses. The most common dermatosis was nevocellular nevi with a prevalence of $30 \%$. Pigmented nevi were highlighted in the general adult population in a series of cohort studies where the prevalence ranged from 9 to $60 \%$ (17-20) to $100 \%$ of cohort members. Although this presence was described in the mentioned studies as being common in the majority of the general population, it was not reported as common among PLWH, perhaps due to its ignorance in various evaluations, as it was not a skin change evocative of HIV infection. This observation is the first time reported in our study to the best of our knowledge. The average age of those who presented such lesions among PLWH was significantly lower (29.8 years) compared to the average age of the general population (49-50 years) in the studies where they were found $(18,20)$.

Infections have been opportunistic diseases associated with HIV-induced immunosuppression since the beginning of the HIV pandemic. In our study, skin, viral, bacterial, or fungal infections had a low prevalence compared to other studies $(21,22)$ where infections were the most common 
Table III. Dermatological manifestations described during the evolution of HIV infection depending on the stage of cellular immunity $(15,16)$ compared to the dermatological manifestations found in the PLWH group.

\begin{tabular}{|c|c|c|c|c|}
\hline \multirow{2}{*}{$\begin{array}{l}\text { Dermatological } \\
\text { manifestations (ref) (year) }\end{array}$} & \multicolumn{4}{|c|}{ Value of $\mathrm{CD} 4^{+}$lymphocytes } \\
\hline & $>500$ cells $/ \mathrm{mm}^{3}$ & $500-200$ cells $/ \mathrm{mm}^{3}$ & $200-100$ cells $/ \mathrm{mm}^{3}$ & $<100$ cells $/ \mathrm{mm}^{3}$ \\
\hline $\begin{array}{l}\text { Dermatological } \\
\text { manifestations (15) (2007) }\end{array}$ & $\begin{array}{l}\text { Acute retroviral } \\
\text { syndrome }\end{array}$ & $\begin{array}{l}\text { Seborrheic } \\
\text { dermatitis } \\
\text { Oral thrush } \\
\text { Prurigo } \\
\text { Xerosis } \\
\text { Kaposi sarcoma }\end{array}$ & $\begin{array}{l}\text { Kaposi sarcoma } \\
\text { Disseminated herpes } \\
\text { simplex } \\
\text { Molluscum } \\
\text { contagiosum } \\
\text { Pruritic papular } \\
\text { eruption } \\
\text { Skin } \\
\text { hyperpigmentation }\end{array}$ & $\begin{array}{l}\text { Chronic cuteneous } \\
\text { mucosal herpes } \\
\text { Cutaneous } \\
\text { cryptococcosis } \\
\text { Histoplasmosis } \\
\text { Disseminated } \\
\text { cytomegalovirus } \\
\text { Skin } \\
\text { hyperpigmentation }\end{array}$ \\
\hline $\begin{array}{l}\text { Dermatological } \\
\text { manifestations (16) (2019) }\end{array}$ & $\begin{array}{l}\text { Acute retroviral } \\
\text { syndrome } \\
\text { Oral hairy leukoplakia } \\
\text { Seborrheic dermatitis } \\
\text { Psoriasis } \\
\text { Kaposi sarcoma }\end{array}$ & $\begin{array}{l}\text { Oral trush } \\
\text { Herpes zoster } \\
\text { Herpes simplex } \\
\text { Refractory } \\
\text { psoriasis } \\
\text { Tinea infection } \\
\text { Verruca vulgaris }\end{array}$ & $\begin{array}{l}\text { Disseminated } \\
\text { herpes simplex } \\
\text { Refractory } \\
\text { seborrheic } \\
\text { dermatitis } \\
\text { Pruritic papular } \\
\text { eruption } \\
\text { Molluscum } \\
\text { contagiosum } \\
\text { Extensive Kaposi's } \\
\text { sarcoma }\end{array}$ & $\begin{array}{l}\text { Chronic extensive } \\
\text { herpes simplex } \\
\text { Cutaneous } \\
\text { cryptococcosis } \\
\text { Disseminated } \\
\text { cytomegalovirus } \\
\text { Aquire dichtiosis } \\
\text { Giant molluscum }\end{array}$ \\
\hline $\begin{array}{l}\text { Dermatological manifestations } \\
\text { in the PLWH group of our study }\end{array}$ & $\begin{array}{l}\text { Pitiriasis versicolor } \\
\text { Seborrheic dermatitis } \\
\text { Herpes simplex } \\
\text { Cutaneous xerosis } \\
\text { Acne } \\
\text { Nevocellular nevi } \\
\text { Vascular abnormalities }\end{array}$ & $\begin{array}{l}\text { Nevocellular nevi } \\
\text { Seborrheic dermatitis } \\
\text { Acne }\end{array}$ & $\begin{array}{l}\text { Folliculitis } \\
\text { Seborrheic } \\
\text { dermatitis }\end{array}$ & $\begin{array}{l}\text { Psoriasis } \\
\text { Skin spots } \\
\text { Vulgar warts } \\
\text { Onychomychosis }\end{array}$ \\
\hline
\end{tabular}

CD4, T-lymphocyte cell bearing CD4 receptor, PLWH, population living with HIV.

dermatoses. Even in the case of a precarious immune status whereby the average value of $\mathrm{CD}^{+}$lymphocytes was below 100 cells $/ \mathrm{mm}^{3}$, bacterial infections represented by folliculitis and impetigo had a low prevalence. The viral infections diagnosed in our patients consisted of vulgar warts and herpes simplex, with a cumulative total of $5.25 \%$. The prevalence of herpes simplex was close to that of the general population (23) but lower than that found in PLWH in Iran (6.7\%) (22).The most common infection was represented by pityriasis versicolor, an external mycosis with a prevalence of $8.8 \%$. In the general population, the prevalence is as high as $50 \%$ in tropical countries and as low as $1.1 \%$ in cold climates such as Sweden $(24,25)$. Other types of fungal infections such as extensive or treatment-resistant candidiasis were not observed in patients in our group. As a peculiarity, patients with pityriasis had an immune status comparable to that of people not infected with HIV, with a mean CD4 ${ }^{+}$lymphocyte $>800$ cells $/ \mathrm{mm}^{3}$ (Table II).

Inflammatory skin pathology, represented by psoriasis was found with a frequency of $1.75 \%$ comparable to that of the general population $(18,19)$; the disease being diagnosed in a patient completely non-adherent to antiretroviral treatment, with CD4 $<100$ cells $/ \mathrm{mm}^{3}$.

The most common dermatological conditions diagnosed in PLWH in our group were those with polymorphic etiology, incompletely known with a cumulative prevalence of $43.7 \%$. Of these, seborrheic dermatitis with a prevalence of $2.35-11.3 \%$ in the general population and $30-80 \%$ in PLWH $(21,25,26)$ had a prevalence of $10.5 \%$ in our Romanian PLWH group, comparable to that in the general population and well below that reported in patients with HIV infection. Another dermatosis recently diagnosed and associated with HIV infection was cutaneous xerosis, with a prevalence of $5.2 \%$; although some studies estimate that it has a prevalence of $20 \%$, being a relatively common skin aspect in HIV infection (26). Xerosis is more common in the extremities, a fact found by our study. The causes of xerosis in PLWH are not fully elucidated but appear to worsen with the decrease in $\mathrm{CD}^{+}$lymphocyte count $(22,26,27)$. A less common cutaneous sign among PLWH but which we identified in $14 \%$ of patients was vascular malformation such as vascular angiomas/microangiomas. 
Although approximately $1 / 5$ of the patients had low levels of immunity $\left(\mathrm{CD} 4<200\right.$ cells $\left./ \mathrm{mm}^{3}\right)$ no case of Kaposi sarcoma was diagnosed. It should be mentioned that almost all patients (except for cases of psoriasis) were examined dermatologically for the first time in this study, because, although aware of some of the skin changes diagnosed on this occasion, they did not seek specialized advice. We could not make any correlation between the stage of immunity and the type of different dermatoses as the average CD4 lymphocyte count was in the range of $400-600$ cells $/ \mathrm{mm}^{3}$ with two exceptions; in the case of bacterial and fungal infections. Even in the case of a precarious immunity (CD4 $<200$ cells $/ \mathrm{mm}^{3}$ ) due to a low therapeutic adherence, we did not encounter these severe dermatoses, evocative of immunosuppression (e.g. molluscum contagiosum) which is a fact found by other authors (22). In addition, no cases of rosacea or cutaneous or palpebral demodicosis were identified (28). As our study shows, the prevalence of different dermatoses varies depending on the geographical region both in the general population $(18-20,23,29,30)$ as well as in PLWH $(17,21,22,26)$. At the same time, under highly active antiretroviral therapy (HAART), the image of dermatoses associated with decreased immunity from HIV infection was altered (Table III), a fact found and highlighted in this study. The study has some limitations due to the relatively small number of patients included; nevertheless, it remains relevant, in our opinion, for the current description of skin health in PLWH.

In conclusion, our study showed that all patients with HIV infection, regardless of age or how they acquired the infection, had various skin changes. Skin changes could not be stratified in correlation with the immune status, the most common being premalignant dermatoses and the heterogeneous group of dermatoses with uncertain etiology. Infectious bacterial, viral or fungal skin pathology characteristic of HIV infection, had a low prevalence. Restoration of immune competence under HAART has brought to the fore those obvious and frequent dermatoses in the general population, at similar degrees of prevalence.

From the perspective of diagnosis, in the presence of HIV-reminiscent dermatoses, such as Kaposi sarcoma or long-lasting extended candidiasis, any dermatologist should also request testing for that patient's HIV infection. However, as we have shown in this study, the skin changes of PLWH no longer fully follow the classical staging, based on the degree of immunosuppression, so that any patient with dermatosis could be potentially infected with HIV. The range of dermatological diseases is getting closer to that of the general population, so that the specification of HIV status is, in our opinion, a mandatory and useful diagnostic approach in conducting subsequent therapy.

In order to get a better insight into the current dermatological pathology in HIV-infected patients in the region, the pathological picture outlined in this study needs to be completed by extending clinical and dermoscopic examination to all HIV-positive patients in active surveillance.

\section{Acknowledgements}

Not applicable.

\section{Funding}

No funding was received.

\section{Availability of data and materials}

The datasets used and/or analyzed during the current study are available from the corresponding author on reasonable request.

\section{Authors' contributions}

Conceptualization of the research and writing of the original draft preparation was carried out by MD. Methodology, writing-review and editing was conducted by GLF and LB. Data analysis was conducted by AI and CD. Investigation and clinical management was performed by DR, CB, EDP, ALT and EN. All authors read and approved the final manuscript to be published and agreed to be accountable for all aspects of the work in ensuring that questions related to the accuracy or integrity of any part of the work.

\section{Ethics approval and consent to participate}

The present study was conducted with the approval of the Ethics Commission of the Infectious Diseases Hospital Sf. Cuv. Parascheva', Galati, Romania (approval no. 65 from 30/09/2019). All patients signed informed consent to participate in this study.

\section{Patient consent for publication}

Not applicable.

\section{Competing interests}

The authors declare no competing interests.

\section{References}

1. Richmon $\mathbf{J}$ and Harris $\mathbf{J}$ : Immunology and skin in health and disease. Cold Spring Harb Perspect Med 4: a015339, 2014.

2. Dybull M, Connors M and Fauci A: The Immunology of human immundeficiency virus. In: Mandell, Douglas and Bennett's Principles and Practice of Infectious Diseases. 6th edition. Publisher Elsevier, Churchill Livingstone, Philadelphia, USA. Khambaty M and Hsu S: Dermatology of the patient with HIV. Emerg Med Clin North Am 28: 355-368, 2010.

3. Khambaty M and Hsu S: Dermatology of the Patient with HIV. EmergClin N Am 28: 355-368, 2010.

4. Sterling $\mathrm{T}$ and Chaisson R: General clinical manifestation of human immundeficiency virus. In: Mandell, Douglas and Bennett's Principles and Practice of Infectious Diseases. 6th edition. Publisher Elsevier, Churchill Livingstone, Philadelphia, USA.

5. Coates SJ and Leslie KS: What's new in HIV dermatology? F1000Res 8: 980, 2019.

6. Vella S, Schwartländer B, Sow SP, Eholie SP and Murphy RL: The history of antiretroviral therapy and of its implementation in resource-limited areas of the world. AIDS 26: 1231-1241, 2012.

7. Săndulescu O, Ţiu I, Jipa R, Streinu-Cercel A, Benea S, Simionescu O, Streinu-Cercel A and Hristea A: Comparison of Kaposi disease outlines in patients with and without HIV infection in two tertiary care hospitals in Bucharest, Romania. BMC Infect Dis 14 (Suppl 7): P20, 2014. 
8. Pavelescu C: Identification of a possible array of specific variations of cytokines in the context of the appearence of cutaneous manifestations in patients with HIV-AIDS in Romania. DermatoVenerol Bucharest 56: 11-19, 2011.

9. Căruntu C, Zurac SA, Jugulete G and Boda D: Extramammary Paget's disease in an HIV-positive patient. Rom J Morphol Embryol 58: 1009-1015, 2017.

10. Boda D, Neagu M, Constantin C, Voinescu RN, Caruntu C, Zurac S, Spandidos DA, Drakoulis N, Tsoukalas D and Tsatsakis AM: HPV strain distribution in patients with genital warts in a female population sample. Oncol Lett 12: 1779-1782, 2016.

11. Iorga L, Dragos Marcu R, Cristina Diaconu C, Maria Alexandra Stanescu A, Pantea Stoian A, Liviu Dorel Mischianu D, Surcel M, Bungau S, Constantin T, Boda D, et al: Penile carcinoma and HPV infection (Review). Exp Ther Med 20: 91-96, 2020.

12. MedCalc setup file 32-bits. Available online: https://www. medcalc.org/. Accessed October 25, 2020.

13. Modrigan M,Draganescu M,Plesea Condratovici C,Lacramioara Pavel L and Plesea Condratovici A: Clinically personality patterns in young adults with HIV nosocomial infection from the region of Southeast Romania. Mater Plastice 54: 175-179, 2017.

14. HIV/AIDS infection in Romania, in the World AIDS Day, 1.12.2018, Analysis of the situation. Available online: http://cnlas. ro/com_jce/date-statistice.html. Accessed March 31, 2020.

15. Caumes E: Dermatological manifestations. In VIH 2007. Girard PM, Katlama C and Ghosn J (eds). Rueil Malmaison, Doin, France, pp159-171, 2007.

16. Tse ICT: Dermatologic manifestations in HIV/AIDS. Online version available at: http://www.aids.gov.hk/pdf/g190htm/21. html. Accessed February 11, 2020

17. Britto GR and Augustine M: Mucocutaneous manifestation of human immunodeficiency virus (HIV) infection in children in relation to the degree of immunosuppression. Int J Dermatol 58 $1165-1171,2019$

18. Schäfer T, Merkl J, Klemm E, Wichmann HE and Ring J; KORA Study Group: The epidemiology of nevi and signs of skin aging in the adult general population: Results of the KORA-survey 2000. J Invest Dermatol 126: 1490-1496, 2006.

19. Svensson A, Ofenloch RF, Bruze M, Naldi L, Cazzaniga S, Elsner P, Goncalo M, Schuttelaar MA and Diepgen TL: Prevalence of skin disease in a population-based sample of adults from five European countries. Br J Dermatol 178: 1111-1118, 2018.

20. Sinikumpu SP, Huilaja L, Jokelainen J, Koiranen M, Auvinen J, Hägg PM, Wikström E, Timonen M and Tasanen K: High prevalence of skin diseases and need for treatment in a middle-aged population. A Northern Finland birth cohort 1966 study. PLoS One 9: e99533, 2014.
21. Motswaledi HM: Common dermatological conditions in the HIV patient. S Afr Fam Pract 61 (Suppl 1): S19-S24, 2019.

22. Davarpanah MA, Motazedian N and Jowkar F: Dermatological manifestations of HIV/AIDS individuals in Shiraz, South of Iran. J Glob Infect Dis 10: 80-83, 2018.

23. Borda LJ, Louis SJ, Fethiere M, Dure D and Morrison BW: Prevalence of skin disease in urban Haiti: A cross-sectional study. Dermatology 235: 495-500, 2019.

24. Karray M and McKinney WP: Tinea (Pityriasis) Versicolor. In: Stat Pearls, StatPearls Publishing, 2020. Available online: https://www.ncbi.nlm.nih.gov/books/NBK482500/. Accessed May 11, 2020.

25. Mathes BM and Douglass MC: Seborrhoeic dermatitis in patients with acquired immunodeficiency syndrome. J Am Acad Dermatol 13: 947-951, 1985.

26. Cedeno-Laurent F, Gómez-Flores M, Mendez N, Ancer-Rodríguez J, Bryant JL, Gaspari AA and Trujillo JR: New insights into HIV-1-primary skin disorders. J Int AIDS Soc 14: 5, 2011 .

27. Voinescu DC, Ciobotaru OR, Ciobotaru OC, Preda A, Lupu VV, Berciu Coman M and Arbune M: Ultrastructural changes of the gastric mucosa induced by the Helicobacter pylori infection. Rev Chim 66: 2104-2108, 2015

28. Tatu AL, Clatici VG and Nwabudike LC: Rosacea-like demodicosis (but not primary demodicosis) and papulopustular rosacea may be two phenotypes of the same disease-a microbioma, therapeutic and diagnostic tools perspective. J Eur Acad Dermatol Venereol 33: e46-e47, 2019.

29. Niculet E, Radaschin DS, Nastase F, Draganescu M, Baroiu L, Miulescu M, Arbune M and Tatu AL: Influence of phytochemicals in induced psoriasis (Review). Exp Ther Med 20: 3421-3424, 2020.

30. Miguel LMZ, Jorge MFS, Rocha B and Miot HA: Incidence of skin diseases diagnosed in a public institution: Comparison between 2003 and 2014. An Bras Dermatol 92: 423-425, 2017.

31. Castro KG, Ward JW, Slutsker L, Buehler JW, Jaffe HW and Berkelman RL: 1993 Revised classification system for HIV infection and expanded surveillance case definition for AIDS among adolescents and adults. MMWR Recomm Rep 41: 1-19, 1992. 